\title{
Cities and Water Security in the Anthropocene: Research Challenges and Opportunities for International Relations
}

\author{
Joana Castro Pereira* \\ Miguel Rodrigues Freitas*
}

\begin{abstract}
Cities have become important actors in international relations, and integral to security and environmental politics. We are living in an increasingly urban world, dominated by human settlements and activities. The central role now played by humans in shaping the planet has led us into an uncertain, unstable, and dangerous geological epoch - the Anthropocene - that poses great and additional challenges to security. Local and global spheres are connected as never before, generating 'glocal' issues in which water plays a central role. Water is the element that interconnects the complex web of food, energy, climate, economic growth, and human security. In a rapidly urbanising world, cities influence the hydrological cycle in major but uncertain ways, affecting water resources beyond their boundaries. There is no doubt that these issues are highly relevant to the discipline of International Relations (IR). However, IR scholars have been slow to engage with them, and most academic studies of cities and water security still emanate from the natural sciences. This article examines the ways in which cities in the Anthropocene challenge water security, and why IR needs to reinvent itself if it wants to sustain its contribution to global security.
\end{abstract}

Keywords: Urbanisation; Cities; Anthropocene; Water Security; Glocal Challenges; International Relations.

\section{Introduction}

The Earth holds more than 1.3 billion cubic kilometres of water. The oceans hold about $97 \%$, and the remaining 3\% occurs in glaciers and ice, below the ground, in rivers and lakes, and in the atmosphere (NOAA 2015). About 70\% of the world's surface is covered by water, but only $2.5 \%$ of it is fresh, and less than $1 \%$ is easily accessible (FAO 2014a). This

* Lusíada University-North (Porto) and Portuguese Institute of International Relations (IPRI-NOVA), Lisbon, Portugal; mail@joanacastropereira.com. ORCID iD 0000-0002-6272-8481.

** University of Minho, Braga, Portugal; miguel.freitas@adp.pt. ORCID iD 0000-0002-0055-8480. 
means that only a tiny amount of the planet's water is available to sustain a growing global population, numbering about 7.3 billion in 2015 (PRB 2015). Over the past five decades, fresh water withdrawals have tripled; indeed, demand for fresh water is increasing by 64 billion cubic metres a year (Worldometers 2015). Over the past century, global water withdrawal has increased 1.7 times faster than populations; about $64 \%$ of water is withdrawn in Asia, and more than half of this occurs in the Southern and Eastern regions, which harbour more than half of the world's population (FAO 2014b). Some 783 million people (about $11 \%$ of the global population) do not have access to clean and safe water, and water scarcity ${ }^{1}$ will continue to be worsened by climate change, salt water intrusion into coastal areas, population growth, deforestation, land degradation, pollution, unsustainable water use, and poor water management (TWP 2014).

Although most water crises occur in the developing world, some of the wealthiest countries are also experiencing growing water-related problems. For instance, California, the eighth largest economy in the world if considered as a country (LAO 2015), has experienced prolonged droughts in recent years. According to the Intergovernmental Panel on Climate Change (IPCC), the proportion of the global population living under waterscarce conditions will increase throughout the $21^{\text {st }}$ century (IPCC 2014). This means that people and nations will increasingly compete for water resources. In addition, the central role played by humans in defining the physical frameworks that regulate major processes of the Earth System ${ }^{2}$ has led us to a new geological epoch - the Anthropocene - which poses major challenges to achieving water security. In this setting, local and global spheres are interconnected, working together to generate 'glocal' challenges (Gupta, Pahl-Wostl and Zondervan 2013; Boccaletti and White 2015).

Cities, as strategic sites of global economic growth, have become important actors in international relations, and integral to security and environmental politics. Cities influence the hydrological cycle in major but uncertain ways, affecting water resources that are largely beyond their boundaries. There is no doubt that this dimension is highly relevant to the discipline of International Relations (IR). However, IR scholars have been slow to engage with these issues, and most academic studies on cities and water security still emanate from the natural sciences. In this article, we will seek to show how cities in the Anthropocene challenge water security; identify the main research gaps as well as the political and practical needs in the water sector that could be explored by IR scholars; and argue that IR needs to reinvent itself in order to address these problems, and remain relevant to the quest for global security.

\section{Water, cities, and the global market society}

We are living in an increasingly urban world. Since 1950, when only 746 million people lived in urban areas, and the planet was still predominantly rural (Vörösmarty et al 2013), the accelerating pace of urbanisation has transformed the global landscape and the functioning of human societies.

According to UN-WWAP (2015), in 2014, 3.9 billion people (i.e. 54\% of the world's population), lived in cities. By 2050, about $66 \%$ of the global population (projected to 
reach 9.7 billion people as reported by UN 2015) will be living in urban areas. About $86 \%$ of the developed world and $64 \%$ of the developing one are expected to be urban (UN 2014).

Large cities, i.e., those with populations greater than 750 000, harbour 1.7 billion people (24\% of the global population), and are responsible for almost 50\% of global GDP (McDonald et al 2014). As the WEF (2011: 111) has noted, 'urbanization will be one of the most important demographic and sociological world mega-trends that we will experience'.

Economic growth thus far has been inseparable from urban growth; similarly, in the coming years, the expansion of the global economy will mostly be associated with the developing of services tailored to emerging urban societies (McDonald et al 2014). Growing urban populations will demand more water, food and energy. If this rapid and deep urbanisation is not accompanied by combined job creation, rising incomes, and substantial levels of social inclusion, cities will be threatened by economic, political and social instability, becoming focal points of general and severe poverty (OECD 2015). This leads us to the water-food-energy security nexus, three strategic resources that are intrinsically linked and essential to the functioning of human societies (UN-Water 2013).

WEF (2011) data suggests that, due to the increasing demand for food as well as changing diets - notably the growing demand for meat as middle classes emerge in many developing countries - food production will need to increase by $70 \%-100 \%$ during the next few decades, resulting in accelerating rates of water use. According to the IEA (2015), world energy demand will grow by more than 30\% up to 2040; most forms of energy production are water-intensive, and highly polluting. As a result, UN-WWAP (2015) projects a $40 \%$ global deficit between water demand and fresh water supply by 2030, and OECD's projections suggest that 3.9 billion people will live under severe water stress ${ }^{3}$ by 2050 (Sadoff et al 2015).

Cities influence the hydrological cycle in various ways: by extracting large amounts of water from surface and ground water sources; discharging untreated waste water into water bodies; and enlarging impermeable surfaces, thus hampering the recharge of groundwater and aggravating flood risks. Cities also import large amounts of food, energy and goods from outside their limits (a virtual water trade that reflects a hidden network of water flows embedded in food or other goods, generating interdependencies between distant global geographies) and generate water pollution that usually flows downstream - in other words, cities impact on water resources far beyond their boundaries (GWP 2012; UN-WWAP 2015; Larsen 2015). Many countries are already facing considerable challenges in securing cities from water risks and providing financially sustainable water and sanitation services to city dwellers (OECD 2014). This is problematic, since water crises in urban areas will probably hamper economic growth, and fuel social unrest. In fact, as the WEF (2011: 112) has argued, 'the story of a successful city rests to a large extent on how it manages its water'. Moreover, water is how humanity experiences the planet's climate, and meeting a growing need for water in rapidly growing urban areas while the world climate is changing will be an enormous challenge (Howard 2015; Bocalletti and White 2015). Adding climate change to the equation results in the complex water-food-energy-climate nexus. 
Most impacts of anthropogenic climate change will affect the water cycle. This will include more frequent droughts, floods and cyclones; rises in sea levels; the melting of glaciers; salt water contamination of water supply wells; and threats to existing water infrastructure, among others (IPCC 2014). Twenty-one of 33 cities with 8 million inhabitants or more (including New York, Tokyo, Cairo and Rio de Janeiro) are coastal, and therefore vulnerable to hydro-meteorological hazards and rises in sea levels (Ljungkvist 2014). Unsurprisingly, therefore, the WEF (2015) regards water crises as the greatest global risk factor for the next decade, followed by the failure of climate change mitigation and adaptation, extreme weather events, food crises, and profound social instability. This is why cities are taking on new roles and responsibilities, engaging in world politics, and seeking international political authority, as participants in global processes of environmental and sustainability governance.

Given that cities are at the heart of production and consumption, they are closely linked to issues of environmental sustainability, and face environmental challenges that will force them to reinvent the ways in which they govern and manage themselves, and coordinate their actions with those of other cities worldwide (Bouteligier 2014). The proliferation of trans-municipal networks (TMNs) for dealing with global issues such as climate change and water-related problems (including the C40 Cities Climate Leadership group ${ }^{4}$ and the Megacities Alliance for Water and Climate ${ }^{5}$ ) indicates the extent to which city-tocity diplomacy has become an important and growing feature of the current international system. Cities are forging horizontal alliances and developing bottom-up commitments, exchanging information, knowledge and expertise. TMNs have been formed by cities on all continents, and co-operate with multilateral institutions that share the same strategies for achieving environmental sustainability (like the World Bank, the UN Environment Programme, and the UN Human Settlements Programme), thus forming the basis for a global agenda and a global environmental governance architecture (Bouteligier 2014; Nijman 2011).

Essentially, cities have become 'glocal' actors - i.e., political actors that are anchored locally but networked globally (Roudometof 2015). This is an innovative move because, for the past three and a half centuries, cities have been fixed within and subordinated to the nation-state; hence, cities have been distant from international relations, security affairs and the conduct of foreign policy, which have all been monopolised by the state (Ljungkvist 2014). Yet, Curtis $(2016: 3,12)$ points out that

the rise of the city also reflects a transformation in the nature of the state itself $[\ldots]$. The new autonomy and capabilities of cities do not replace or challenge the agency of states and the state-system. [...] The empowerment of cities is a product of state rescaling strategies.

According to Curtis (2014b, 2016), the emergence of cities is the result of the transnational capitalist economic structure that emerged after the rise of neoliberalism in the 1970 s - committed to free markets, the free movement of capital, and minimal state intervention in economic affairs - and paved the way for the transnational corporation and the market state. Rather than seeking to maximise its citizens' welfare (as during 'The 
Glorious Thirty'), the neoliberal state seeks to promote the former's economic opportunities, by redistributing resources into private hands. Unlike the nation-state, the decisionmaking spheres of market states transcend traditional state borders, and the traditional sovereignty-based international order. This means that securing the new flows of value that run through global urban networks has become more important than securing traditional borders. Given that market states are no longer capable of securing the welfare of their citizens, securing access to and opportunities in global markets have become their primary promise.

In this new decentralised order, enhanced by profound developments in digital information and communications technologies in the last decades of the $20^{\text {th }}$ century, cities have assumed a pivotal role as spatial command posts for global capitalism. Their proximity to the local, transnational reach, and ability to bridge these two scales have led to a new relationship between the state and the city. States delegate their authority to other actors, blending public and private governance, recalibrating their authority, and empowering cities. In fact, in this decentred and diffuse world, nation-states are no longer able to protect their citizens against the adverse effects of global economic flows as well as other transnational risks. Consequently, cities have assumed new roles in the absence of effective state action, filling the gaps left by the nation-state. Essentially, cities have also emerged in the international system as the state's response to the mismatch between the transnational scale of the most pressing problems faced by humanity, such as environmental ones, and the territorial and sovereign international order.

Nevertheless, as Bulkeley and Broto (2013: 361) observe, even though cities have been recognised as important actors in responding to environmental problems, 'the translation of political commitments and policy rhetoric into substantial and programmatic municipal responses has been limited'. Furthermore, the greening of many cities in the developed world seems to depend upon the displacement of heavy industrial activities to the developing one, a fact that raises significant questions about the environmental sustainability of the green path followed by wealthy cities (Janos and McKendry 2014). Actually, the main TMNs dealing with environmental issues are tied to the logics of the neoliberal global order, collaborating with powerful multi-national corporations and private foundations, and formulating solutions based on the philosophy of markets (Curtis 2016). This track is unsustainable. 'A revolution in human consciousness' (Falk 2016: 97) is needed, because 'the planet is telling us that there are limits to human freedom; there are freedoms and political [and economic] choices we can no longer have' (Burke et al 2016: 9).

To begin this revolution, and as Rademacher (2015: 138) asserts, 'humans must confront the material and social experience of living on a planet dominated by concentrated human settlements and their associated processes as never before'. Also, and fundamentally, humans must realise that their activities have become a dominant force in global environmental change (Rockström et al 2009), and humanity is now a geological agent (Zalasiewicz et al 2010) - in other words, that we are living in the Anthropocene (Crutzen and Stoermer 2000). 


\section{Water and the Anthropocene}

The Anthropocene is a new geological epoch in which humans play a central role in subverting the Earth System, i.e., in changing the physical framework that regulates its major processes (Steffen, Crutzen and McNeil 2007). The term was coined by Crutzen and Stoermer in 2000 to draw attention to the fact that humans are playing an increasingly dominant role in shaping the global environment.

The new world of the Anthropocene is dangerous, complex, unstable and uncertain (Dean, Leng and Mackay 2014), differing significantly from the Holocene, the world humans lived in during the previous 10000 years. This was an epoch of relative environmental stability, in which human civilizations prospered and created the complex societies of modern times (Zalasiewicz et al 2010). Nevertheless, as noted by Gillings and HaganLawson (2014), since these modern societies have developed under rather stable and predictable environments, it is not certain that humans will have the capacity to adapt quickly enough to assimilate these transformations. Moreover, many of the human-produced developments of the Anthropocene have no parallel in history, and work in complex, uncertain and unpredictable ways (Arighostiles 2015) that threaten economies and societies. In addition, the time lag between causes and results in complex Earth Systems means that preventing causes now will probably not stop what is already in progress (Gillings and Hagan-Lawson 2014). This is overwhelming, especially because ecologists and biologists are discussing whether the planet is entering a sixth great extinction phase (Kolbert 2014). Therefore, and because there is no outside agent to blame (as in previous great extinction events), the Anthropocene poses profound questions about the current human development paradigm.

This is why optimistic environmental programmes such as the Ecomodernist Manifesto (Asafu-Adjaye et al 2015) are dangerous and imprudent. Exalting modern human technologies and the features of anthropocentric societies - and blindly believing that they are capable of securing humanity and sparing nature - ecomodernists go as far as to assert that 'the case for a more active, conscious, and accelerated decoupling to spare nature draws more on spiritual or aesthetic than on material or utilitarian arguments' (Asafu-Adjaye et al 2015: 25). This type of statement is not only inconsistent with a sixth great extinction event, but also promotes inertia when what the worlds needs most is vigorous action. Even though collapses associated with the excessive consumption of resources are not historically unprecedented, they previously occurred as isolated cases; now the threat of a breakdown affecting the entire planet constitutes a new challenge for humanity (Bogardi, Fekete and Vörösmarty 2013). In the words of Nicholson and Jinnah (2016: 1), we are living in 'an Earth 2.0 on which the human signature is everywhere, and in desperate need of humane and insightful guidance'.

In this context, Rockström et al (2009) have defined nine 'planetary boundaries' that outline the most pressing dimensions of the global sustainability problem emerging from the scale and speed of human interventions in the Earth System; crossing these boundaries may possibly result in abrupt or irreversible environmental changes. They are stratospheric ozone depletion; biodiversity loss and extinctions; chemical pollution and the re- 
lease of novel entities; climate change; ocean acidification; land system change; nitrogen and phosphorus flows to the biosphere and oceans; atmospheric aerosol loading; and, naturally, fresh water consumption and the global hydrological system.

Since the beginning of the Industrial Revolution, direct human efforts to manage water, as well as transformations in urban and rural land use that affected the flow and storage of water, changed the distribution of freshwater on the face of the planet. As reported by Savenije, Hoekstra and van der Zaag (2014: 320), humans have altered the hydrological response of various watersheds through:

a) direct diversion of water flows, including inter-basin transfers for water supplies to cities, industries and agriculture, b) transformation of the stream network, for example through the construction of dams and reservoirs or the canalization of rivers, c) changing drainage basin characteristics, for example through deforestation, urbanization, drainage of wetlands and agricultural practices and d) activities altering the regional or global climate, for instance by enhancing greenhouse gas emissions, land-cover changes, and consumptive water use.

Besides increasing levels of pollution, industrial innovations gave birth to a new generation of engineers who believed that nature could be 'tamed' and made orderly. However, the manifestations of the Anthropocene prove that 'nature talks back' when humans cross certain limits (Savenije, Hoekstra and van der Zaag 2014). Decreases in groundwater and lake levels, as well as the extinction of wetlands, reveal that many of the usual uses of water systems are unsustainable. According to Rockström et al (2009), if one assumes an upper limit of 12 500-15 000 cubic kilometres a year of accessible blue water resources, consumption of more than 4000-6000 cubic kilometres a year would constitute a significant risk to ecosystems, moisture feedbacks, and freshwater/ocean mixing. Although current levels of water consumption are 2600 cubic metres a year, trends of accelerating water consumption in a new world of rapid change and instability, with increasing chances of reaching tipping points, are disturbing (Berkhout 2015), especially if one takes into account that precipitation, the source of all freshwater, is no longer stable and predictable, and that the Anthropocene includes the challenge of supplying freshwater to more than 9 billion people by 2050 (Rockström et al 2014). Consequently, as highlighted by Shi et al (2015: 135), this challenge 'necessitates radical and systemic changes to the design and function of cities, and relationships between the environment and society'.

In the Anthropocene, as Vörösmarty, Pahl-Wostl and Bhaduri (2013: 1) point out, 'humans are changing the global water system in a globally significant way without adequate knowledge of the system, and thus its response to change. Moreover, human actions are and will probably remain the main elements in defining future patterns of water scarcity (Pahl-Wostl et al 2013). However, the impacts of the Anthropocene on water are poorly understood, so the study of the hydrological effects of this new geological epoch should be a priority for researchers (Wheater 2015). At least, it should be noted that rec- 
ognition of the Anthropocene has rekindled the debate over the concept of water security, and motivated reflection on water paradigms (Schoeman, Allan and Finlayson 2014).

\section{Water security in the Anthropocene}

There are several definitions and understandings of 'water security'; some of them have a narrower focus, and represent particular interests. Because 'water is a prerequisite for human health, food production and the generation of all other ecosystem services' (Rockström et al 2014), linking together the complex dimensions of food, energy, climate, economic growth and human security (WEF 2011), and therefore the 'the delivery mechanism for the effects of climate change on people, communities, and ecosystems' (Conca 2016: 38), a mutually agreed upon and holistic definition is needed to address the huge water challenges currently faced by humans. In this context, we use the perspective adopted by the UN-Water working definition on water security, which seeks to fill that gap by integrating the core elements required to achieving and maintaining water security. According to UN-Water (2013: 1), water security is

the capacity of a population to safeguard sustainable access to adequate quantities of acceptable quality water for sustaining livelihoods, human well-being, and socio-economic development, for ensuring protection against water-borne pollution and water-related disasters, and for preserving ecosystems in a climate of peace and political stability.

This definition - in line with the UN Sustainable Development Goals, 'a set of goals to end poverty, protect the planet, and ensure prosperity for all' (UN n.d.) - integrates four core elements that entail the present and future health of populations and systems (UNWater 2013: 2):

1. Drinking water and human well-being: people have access to safe and sufficient drinking water at an affordable price to satisfy basic needs (such as sanitation and hygiene) and protect health and well-being, thus fulfilling fundamental human rights;

2. Economic activities and development: water supplies for socio-economic development and activities (e.g.: energy, transport, industry and tourism);

3. Ecosystems: preservation and protection of ecosystems in terms of water allocation and management systems, seeking their capacity to deliver and maintain the functioning of ecosystem services;

4. Water-related hazards and climate change: resilience to water-related hazards (for instance, droughts, floods and pollution).

Given that nearly $80 \%$ of the world's population confronts a high-level water security or water-related biodiversity risk (Vörösmarty et al 2010), studies on water security have attracted considerable attention. However, as Bakker (2012) has written, most academic studies on this topic are distant from the needs of policy-makers and practitioners. As noted by Pahl-Wostl et al (2013: 709), there are 'major missing links between knowledge 
generation and policy framing. This is a failure in academic research, because coping with the instability and uncertainty of the Anthropocene will require close co-operation among scientists, policy-makers and practitioners as well as among natural sciences, social sciences and humanities (Schoeman, Allan and Finlayson 2014; Pereira 2016); the aforementioned four key elements implied in the working definition of water security make this co-ordination mandatory. On this new planet, 'one role for scholarship [...] is to provide those working more directly for social change with the knowledge and tools required for their efforts' (Nicholson and Jinnah 2016: 10). Thus, the Anthropocene brings with it the opportunity and the necessity for real transdisciplinary research work (Gillings and Hagan-Lawson 2014). As a result, new approaches have been emerging. Perhaps the most promising is socio-hydrology, a new discipline tailored to deal with water issues in the Anthropocene that draws insights from hydrologists, natural and social scientists, and humanists (Sivapalan et al 2014). Furthermore, the Anthropocene, characterised by longterm effects and uncertainties, makes the future a much less stable object of study (Sivapalan et al 2014; Berkhout 2015); hence, scientists, policy-makers and practitioners must be prepared for various futures, i.e., for several possible scenarios. Moreover, different regions have different security issues, and consequently there will be many Anthropocene futures, depending on where people stand and who they are - therefore, the requirements for achieving water security will vary, especially between developed and developing regions or countries, and 'mature' and 'developing' water resources management systems (Allan, Xia and Pahl-Wostl 2013; Berkhout 2015).

The emphasis has usually been on cities in developing nations, notably the BRICS countries, but OECD countries also face significant and distinctive water management challenges (OECD 2014). Finally, researchers have been focusing their attention on identifying problems; instead, the time has come to shift towards 'a new era of solution-oriented research' (Pahl-Wostl et al 2013: 710). Nevertheless, as Biermann and Young (2016: xi) note,

such research is no easy undertaking. It must span the entire globe because only integrated global solutions can ensure a sustainable coevolution of biophysical and socioeconomic systems. But it must also draw on local experiences and insights. [...] The task is to develop integrated systems of governance from the local to the global level, that ensure the sustainable development of the coupled socioecological system that the Earth has become.

In sum, integrated paradigms for bridging the science-policy divide (Vörösmarty, Pahl-Wostl and Bhaduri 2013); a long-term vision for the future; a recognition that there will be 'different Anthropocenes' around the world (Berkhout 2015); and solution-oriented approaches from the local to the global level are central to dealing with the water challenge. Managing water through these 'lenses' will help us get to water security. However, managing water itself has been a complex and controversial task. 


\section{Water resources management}

The Anthropocene challenges conventional water management approaches. Until recently, command-and-control management was the dominant approach. This relies on assumptions of stability, predictable uncertainty and the reversibility of trajectories of change within natural systems, aiming at maximizing water exploitation by reducing natural variability. Centralisation, sectoral institutions, restricted stakeholder participation, and a focus on technical engineering solutions are central features of this management approach (Schoeman, Allan and Finlayson 2014). As we have seen, the complexity and unpredictability associated with the Anthropocene make this approach obsolete, and there is strong and increasing evidence that conventional water management approaches have failed to ensure water security. This recognition paved the way for integrated water resources management (IWRM), a concept officially adopted at the International Conference on Water and the Environment, held in Dublin in 1992 (Savenije, Hoekstra and van der Zaag 2014).

According to the Global Water Partnership definition (2012: 4), IWRM is a water management perspective encompassing 'a holistic approach that better integrates water into socio-economic development planning in order to simultaneously achieve economic efficiency, social equity and environmental sustainability'. It is characterised by an intersectoral approach, taking into account the need of multiple uses, and co-ordinating management among water, land and associated resources. Therefore, it goes beyond the water sector and stresses the need to reflect upon other resource systems particularly when observing a problem linked to water (Pflieger 2016). Nevertheless, empirical studies reveal that IWRM's benefits have been minimal due to the vagueness of the concept and its lack of focus on 'learning by doing'. Consequently, the concept of adaptive water management (AWM) was proposed to truly integrating uncertainty as a central element in water management (Savenije, Hoekstra and van der Zaag 2014). Assuming that people and ecosystems are uncertain and difficult to control, AWM uses feedbacks from nature to shape policies, placing systematic experimentation and learning in an incessant cycle (Schoeman, Allan and Finlayson 2014). However, AWM's complexity, costs and risks, as well as institutional resistance to reflection before action, have also limited its success (Rist et al 2013).

Furthermore, three are major issues associated with water management that make it even more difficult for managers, decision-makers and politicians to effectively deal with water issues: water uses, water rules, and the territoriality of water resources. Over the past two centuries, the use of water has increased and diversified, leading to the development of a regulatory field for water as well as a diversification of the rules. Modern societies have developed a wide range of regulations for governing the uses of water, which have become increasingly diverse and accumulated (laws are rarely abolished or removed). There are regulations at the municipal, regional, inter-regional and national levels, as well as international guidelines. Sometimes, these sets of rules conflict with one another, promoting a lack of coherence that undermines the fair management of water resources, and hinders the achievement of water security. As regards territoriality, the increase and diversification of water uses make it clear that rivers have no borders. For instance, if an upstream state 
or city pollutes a river, downstream ones will have difficulties in using this resource efficiently and fairly (Pflieger 2016). Hence, a key question today about the management of water resources is 'how can cities contribute to water resources management, minimising pressure on freshwater resources upstream and downstream' (OECD 2014: 1). Rapid urbanisation and population growth will inevitably have consequences for the way in which water is managed across administrative and hydrological boundaries, making it more difficult to develop solutions.

\section{Engaging cities in 'glocal' water governance}

As we have seen, the increasing demand for water in an increasingly urbanised world, as well as human-induced changes in the global water cycle that enhance droughts, floods, and the uncertainty of precipitation patterns, pose deep challenges to the management of water resources. As a result, the way in which cities develop and manage their water will have a huge impact on water security. Cities, which are expected to house two thirds of the global population by 2050, thus run a serious risk of descending into social tensions, conflicts and even wars that will destabilise not only regions but also the world order. Therefore, achieving water security is a global challenge. However, environmental impacts related to water use and consumption are essentially felt locally and regionally. Unlike other global environmental challenges such as climate change mitigation, managing water resources depends upon the local context, where the simple reduction of water consumption is not necessarily synonymous with better water management (Wichelns 2015). For instance, reducing carbon emissions anywhere in the world at any time reduces the global pressure on the atmosphere; however, this is not true about the reduction of water consumption and its related impacts. The sustainable management of water resources depends on the geographical (water-abundant or water-scarce regions), temporal (when water is used due to intra-annual variability), and socioeconomic aspects that rely on them (Wichelns 2015). This is why water security is a 'glocal' challenge, requiring co-operation among local agents. We use the term 'glocal' because it draws attention to the micro-level forces that can play an active role in large-scale macro-processes (on 'glocalisation' see, for instance, Roudometof 2015), as well as the local singularities and constraints that need to be taken into account in the quest for global water security.

Existing trans-municipal sustainability networks focus on transferring expertise, attracting financial support for building infrastructure, and the implementing mitigation and adaptation measures (Boutlegier 2014) cities need to increase their resilience to droughts and floods. Although, as discussed earlier, the practical results of these initiatives have been poor - because they are tied to the logics of the neoliberal economic order, offering short-term solutions that are inadequate in the Anthropocene - this is an important part of achieving water security. Informed and innovative approaches and bridging the science-policy gap are essential to promoting new practices through TMNs, and dealing with the complexity, instability and uncertainty of the planet's new geological conditions. However, cities can develop another crucial role in this regard, associated with a stronger relationship between local political authorities and civil society groups. Active civil soci- 
eties in various cities, acting together and co-operating with local government, may have a significant role to play in protecting ecosystems and embarking on the paradigm shift needed to make water use compatible with economic activities and development. In the case of cities sharing the same watershed, these groups could co-operate to preserve the ecosystems of their region's watercourses, and supervise water uses to ensure that they do not jeopardise local development and socioeconomic activities. This would link citizens internationally, in the case of transnational watersheds. A network of civil society groups may help raise public awareness about harmful activities, and pressure local governments to act. Today, the efficacy of these groups can be enhanced by the use of social media networks. ${ }^{6}$ They could also force decision-makers to embrace all stakeholders when making decisions about the management of water resources, promoting platforms for discussion in which citizens are also represented, and have an active voice.

Local political authorities must dare to change 'with' people, and not only 'for' the people. In the case of cities that do not share the same watershed, civil society groups may exchange knowledge and practices for changing human consciousness with regard to individual impacts on water resources and in the global environment. This is imperative, because the new conditions of the Anthropocene and their impacts on water require new relationships between the environment and society. Widespread support for changes in our daily consumption habits would help mitigate the global pressure on water resources, potentially influencing the production of goods in different and distant geographies (Hoekstra 2014). Trans-municipal sustainability networks and civil society networks, acting as previously described, could address the four core elements of the UN-Water working definition on water security.

As Chan (2016) argues, cities are in a unique position to connect their citizens with global initiatives, because there is a closer relationship between citizens and municipal political authorities, and because cities have no sovereign obligations and easily engage with other cities to 'get the jobs done'. In the process, as Nijman (2011) notes, citizens do not lose their sense of belonging to the urban political society, and can develop a sense of 'rooted cosmopolitanism' in a globalised world, working to protect the Earth. Cities are thus able to take part in 'glocal' governance. Nevertheless, to truly engage with the planetary realm, city mayors and citizens alike must be aware of the gravity of the global environmental crisis, and enlightened about the meaning and consequences of the Anthropocene. This is where academia comes in.

\section{Research challenges and opportunities for IR}

Surprisingly, cities, water security, and the notion of the Anthropocene are overlooked elements in IR. Thus Nicholson and Jinnah (2016: 2) ask:

Are we, as a community of students and scholars, doing the right things in the right ways? Is the field keeping pace with the environmental, social, political, and economic challenges presented by 
a rapidly changing world? Are we collectively up to the challenges presented by a New Earth?

The answer is no. As Mitchell (2016: 2) has noted, 'IR is one of a few disciplines that are explicitly and profoundly occupied with the issue[s] of [security and] survival on a global scale'. However, as we shall see below, if IR is to remain relevant, and contribute meaningfully to global security, scholars must rethink many of their basic assumptions and bring new actors, issues and approaches to the forefront. We will now focus on a number of key IR beliefs that hinder its capacity to engage with the growing role of cities in global politics, environmental issues such as water security, and the new conditions of the Anthropocene - as we have seen, three trends and topics that must be taken into account for a true understanding of the real world.

In the urban and anthropocentric era we have analysed in this article, cities have become actors in global politics. Yet, IR scholars have largely disregarded the role of cities in the current international system (Acuto 2013; Curtis 2014; Chan 2016; Gordon 2016). Despite attempts at renewing and expanding IR - i.e., moving away from its mainstream framing and agenda - the field keeps returning to its conventional modes of thinking (Heng 2010): IR as a state-centric discipline that studies - through a positivist/rationalist point of a view, and stuck in its own reductionist disciplinary assumptions - an anarchic, competitive, and violent international system divided by territorial boundaries into sovereign states (Burke et al 2016; Rosenberg 2016). This means that, in IR scholarship, cities are considered as sub-national political entities (Curtis 2014) that are beyond the scope of the discipline's subject of study, namely interstate relations and the forms of international organisation allowed by them. As Chan (2016: 134-138) notes,

a multi-centric model of diverse and relatively autonomous nonstate actors has emerged and coexisted with the older orderings. [...] [However,] while we live in a twenty-first century world of interdependence, we face seventeenth-century Westphalian political institutions $s^{7}$ with defined boundaries and separated responsibilities of nation-states. [...] the current inter-state system fails to fight many of the world's fights which are transborder in nature, global in scale.

Like the current interstate system and Westphalian political institutions, IR has also failed to effectively address the 'glocal' challenges facing humanity - not only because its 'state-centric blindness' makes it difficult to see other types of development (like the emergence of cities in international affairs), but also because the dominant positivist and rationalist paradigms in the field, as well as the lack of true interdisciplinary or transdisciplinary work, make it impossible to keep pace with the magnitude of contemporary transformations (Dalby 2011).

The prevailing rationalist theory and positivist method assume that there is a static world outside that can be perfectly assimilated and anticipated. Hence, as Kavalski (2015) notes, 
IR usually presents 'explanations premised on assumptions of predictability rooted in the conviction that international life is a closed system, changing in a gradual manner and following linear trajectories, which can be elicited through discrete assessments of dependent and independent variables.

However, as noted earlier, the world of the Anthropocene is complex, uncertain, unstable, and unpredictable. As a result, IR should be working on identifying and preparing for various alternative futures, because the future is open, and there is no 'one truth' (Booth 1995; Pereira 2013). Non-linearities, unexpected change, and feedback effects are all intrinsic to the Anthropocene, so past actions, experiences and institutional designs are not a reliable guide to the future (Crawford 2016; O'Neill 2016; Young 2016). Regarding the vital issue of water security and water management, IR scholars should be improving their ability to imagine numerous scenarios and develop several skills for different situations, because these will certainly help them to provide iterative responses and guide policy-makers to informed actions (bridging the science-policy divide that persists in the water sector). This will be crucial, for instance, in guiding city mayors who are managing watersheds through TMN coalitions. Moreover, since the Anthropocene links the natural, social and human sciences, IR will have to embrace theories and methods from other disciplines and fields in order to provide the holistic picture of reality that the complex task of achieving water security in this new geological epoch demands.

Consequently, IR will also, as Fagan (2016) has noted, have to abandon one of the 'key organizing logics of upon which much of [its] security discourse is built': the distinction between humans and nature. Cudworth and Hobden (2015) draw attention to the fact that environmental security has to move from the idea of providing security for something 'out there' to an emphasis on transforming the human development paradigm, because humanity is now a geological agent, and human survival or extinction now depends on human actions. In this regard, IR scholars could help city mayors to think about alternative modes of securing the environment and water, challenging the dominant logics of the global market society. As Burke et al have noted (2016: 2):

We don't need more reports or policy debates. We need new practices, new ideas, stories, and myths. [...] [IR scholars must help to create] a politics to nurture worlds for all humans and species coliving in the biosphere.

This idea leads us to another important feature of the international system of the Anthropocene, namely that it encompasses much more than the interactions among states, international organisations, or even cities. Since humans and nature are inseparable, humans, non-humans and biophysical elements all interact in shaping the complex web of global life (Cudworth and Hobden 2015). The world is not fully subject to human control, and events are not only the result of human agency (Connolly 2011). Moreover, 'harm does not happen to humans in isolation, but rather to worlds composed of diverse beings' (Mitchell 2014: 5). Nevertheless, 'the human' has been the absolute subject of security 
in IR and security studies - in other words, the field is deeply anthropocentric (Bousquets 2015). Essentially, the dominant conception of security, concentrating only on human well-being, tends to instrumentalise non-humans, which means that even the nonessential needs of human beings are prioritised in relation to the survival of non-humans (Mitchell 2014).

This approach is failing to respond effectively to the new conditions and threats of the Anthropocene. The world is not exclusively ours. Human, natural and material actors are all entangled (Burke et al 2016); therefore, it is time to value non-humans not only because they are valuable to us, but also, and fundamentally, because they exist, and their existence is as valuable as our own. This ethical approach is key to the achievement of water security: only by recognizing the intrinsic value of water can humanity secure the global hydrological system and achieve the four core elements of the UN-Water (2013) working definition of water security, especially the preservation and protection of ecosystems. Managing our 'ecospace', i.e., 'the space that people can use if they want to sustain the earth's resources' (Gupta 2016: 272), requires a fair sharing of the planet between humans, and between humans and non-humans.

One last 'old habit' IR scholars will have to abandon is their distant attitude towards environmental issues (see Keohane 2015). Why is the field overlooking one of the most global and pressing challenges humanity faces? Maybe because, as we can see throughout this section, the complexity and scale of environmental problems, as well as the essence of the Anthropocene, disturb IR's dominant structure. Moreover, as underlined by Dauvergne and Clapp (2016: 3), founders of the prestigious journal Global Environmental Politics, the ones who dedicate themselves to the study of global environmental change seem to

focus on formal state-based environmental governance [...] [dealing with] regimes or international agreements as a primary thematic focus, with topics ranging from how to measure the effectiveness of regimes to why states chose to ratify or oppose specific treaties.

This corroborates that important actors like cities are indeed being disregarded and that IR remains state-centric, limiting its capacity to truly understand the new Earth. The number of IR scholars studying environmental issues may also be decreasing. While in 2003 political scientists and IR scholars constituted over $60 \%$ of authors writing in Global Environmental Politics, this figure dropped to under 40\% in 2011 (Dauvergne and Clapp 2016: 9). As regards ideology, very few authors adopt a critical political economy approach, which means that there is little effort to think about alternatives for the global market society (Dauvergne and Clapp 2016: 8). Actually, if one searches for articles about water, the Anthropocene, and cities in the Web of Science Core Collection database, one realises that the vast majority of them come from the natural sciences, and that IR is very far removed from these issues.

These are too many fails for a discipline that claims to be devoted to survival. On this new planet, IR scholars should be playing an active role in problem-oriented research. 
Yet, as Erskine and Booth (2016: 280) note, IR has been too distracted by its 'own carefully cultivated, inward-looking theoretical projects that [...] [it fails] to respond to those real-world threats that it supposedly exists to address'. This is also visible in articles published in Global Environmental Politics: 'GEP scholars are clustering around ever-smaller academic debates, potentially alienating them from policy and activist communities (and at times, even from other academics)' (Dauvergne and Clapp 2016).

The truth is that IR is deeply abstract, resulting in a discipline that is theoretically accurate but not very relevant (Sylvester 2016). To help solve glocal challenges, IR scholars must understand that, although abstractions and theories are an important part of scientific research, they end up being useless if they do not engage real people and problems in the real world.

As we have seen, the world is urban, most people now live in cities, and their activities are the dominant influence over vital environmental issues such water resources. Water is how we will experience climate change, and water crises in urban areas will translate into economic and social chaos. Rivers have no borders, so the management of our common water resources have little to do with nationalities and sovereignty. States have proven incapable of coming up with solutions that serve the interests of both humans and the Earth. Because scholars have a moral and ethical responsibility towards the planet, they should be working with citizens to create a transnational social movement that is informed, creative, motivated, and committed to the survival of the Earth as a whole. The fact that cities are central elements of the dominant capitalist paradigm reinforces the need to engage with citizens, enlighten people, and help create the 'revolution in human consciousness' that will give them the power to pressure local governments. Why not start this revolution with caring for water, the source of all life?

\section{Conclusion}

We have sought to draw attention to the challenging task of achieving water security in the urban world of the Anthropocene (and ultimately to the survival of the Earth as we know it), as well as the limits of IR in responding to the new conditions of a planet whose ecological boundaries are being pushed like never before. In focusing on the vital issue of water security, we intended to question the path modernity has taken, and call not only for an 'Earth consciousness', but also for a new era grounded on ethics and moral activism. If IR scholars, whose primary concerns are global security and survival, do not actively build reliable alternatives for the dominant paradigms that are failing the planet, who else will do it? Moreover, if IR does not rethink and rewrite itself, it will lose its relevance and become extinct. However, it is not too late to transform the discipline and help create a 'glocal sustainable development governance system' aimed at securing humans and nonhumans.

Urban societies are and will continue to be at the centre of the global ecological crisis, both as the engines of the increasing demand for natural resources, and arenas where solutions have to be found. Informed, inventive, and motivated city mayors and citizens have 
an important role to play in avoiding social instability, starting with addressing the urgent water crisis. Almost all economic activities and human development rely on the sustainable and efficient management of water resources. Strategies for achieving water security have to be locally designed, taking into account the hydrologic, political and socioeconomic contexts, and involving all local stakeholders. There is no one-size-fits-all answer. Hence we have argued that global water security depends on the efficacy of TMNs and the dynamism of civil society networks in pressuring local governments and co-operating on protecting water resources. Cities and their citizens have the potential to begin a paradigm shift in the way in which we relate to nature, and create a safe space for humanity. Academics must provide them with the knowledge and tools for transforming potential into power.

Despite the gravity of the planetary real, we write with optimism and hope in 'the productive role that an engaged academy can play in the face of environmental decline' (Nicholson and Jinnah 2016: 1). As Baba Dioum - a remarkable African naturalist and founding member of the International Union for Conservation of Nature and Natural Resources (IUCN) - brilliantly asserted in a speech to the General Assembly of the IUCN in 1968, 'in the end we will conserve only what we love, we will love only what we understand, and we will understand only what we are taught. Let us teach the world to understand, love, and conserve the Earth.

\section{Notes}

1 According to the ICA (2012: i), water scarcity occurs 'when a country or region's annual water supply is less than 1000 cubic meters per person per year'.

2 This term was adopted in the 1990s to reflect the growing insight that the various fields covered by the Earth sciences were closely interconnected. This has led to the introduction of Earth System Science at a growing number of universities around the world. The UN Environmental Programme (2012: 195) has defined the Earth System as follows: 'The Earth System is a complex social-environmental system, including the vast collection of interacting physical, chemical, biological and social components and processes that determine the state and evolution of the planet and life on it. The biophysical components of the Earth System are often referred to as spheres: atmosphere, biosphere, hydrosphere and geosphere. They provide environmental processes that regulate the functioning of the Earth, such as the climate system, the ecological services generated by the living biosphere, including food production, and natural resources like fossil fuels and minerals. Humans are an integral part of the Earth System.'

3 According to the ICA (2012: i), water stress occurs 'when a country's or region's annual water supply is less than 1700 cubic meters per person per year'.

4 See http://www.c40.org/.

5 See https://eaumega.org/.

6 For instance, in February 2016, Portuguese politicians and judicial authorities took action regarding industrial pollutant discharges occurring upstream of Lisbon in the Tagus river basin, because of a video shared through social media networks by local citizens. See: http://ionline.sapo.pt/496347.

7 On the Westphalian and post-Westphalian features of the current international system, see Pereira (2015). 


\section{References}

Acuto, Michele. 2013. Global Cities, Governance and Diplomacy: The Urban Link. London: Routledge.

Allan, Catherine, Jun Xia and Claudia Pahl-Wostl. 2013. 'Climate change and water security: challenges for adaptive water management'. Current Opinion in Environmental Sustainability, 5(6): 625632.

Arighostiles, Olivia. 2015. 'The Anthropocene - why does it matter for policymakers?' Government Gazette [online]. 24 April. At http://governmentgazette.eu/?p=6273. [Accessed on 6 February 2016]. Asafu-Adjaye, John et al. 2015. 'An Ecomodernist Manifesto' [online]. At http://www.ecomodernism.org/manifesto-english/. [Accessed on 21 March 2016].

Bakker, Karen. 2012. 'Water security: research challenges and opportunities'. Science, 337 (6097): 914-915.

Berkhout, Frans. 2015. 'Anthropocene futures and water security'. Proceedings of the International Association of Hydrological Sciences, 366: 31-33.

Biermann, Frank and Oran R Young. 2016. 'Series foreword'. In Simon Nicholson and Sikina Jinnah (eds), New Earth Politics: Essays from the Anthropocene. Cambridge: The MIT Press, pp xi-xii.

Boccaletti, Giulio and Gary White. 2015. 'Why we need to address global water security now'. World Economic Forum [online]. 2 December. At https://www.weforum.org/agenda/2015/12/why-weneed-to-address-global-water-security-now/. [Accessed on 10 March 2016].

Bogardi, Janos J, Balázs M Fekete and Charles J Vörösmarty. 2013. 'Planetary boundaries revisited: a view through the "water lens"'. Current Opinion in Environmental Sustainability, 5(6): 581-589.

Booth, Ken. 1995. 'Dare not to know: International Relations theory versus the future'. In Ken Booth and Steve Smith (eds), International Relations Theory Today. Cambridge: Polity Press, pp. 328-350.

Bousquets, Antoine. 2015. 'Prolegomena to postanthropocentric International Relations: biosphere and technosphere in the age of global complexity'. In Emilian Kavalski (ed), World Politics at the Edge of Chaos: Reflections on Complexity and Global Life. New York: State University of New York Press. Kindle Edition.

Bouteligier, Sofie. 2014. 'A networked urban world: empowering cities to tackle environmental challenges'. In Simon Curtis (ed), The Power of Cities in International Relations. New York: Routledge, pp. 57-68.

Bulkeley, Harriet and Vanessa C Broto. 2013. 'Government by experiment? Global cities and the governing of climate change. Transactions of the Institute of British Geographers, 38(3): 361-375.

Burke, Anthony, Stefanie Fishel, Audra Mitchell, Simon Dalby and Daniel J Levine. 2016. 'Planet Politics: a manifesto from the end of IR'. Millennium, 44(3): 499-523.

Chan, Dan K. 2016. 'City diplomacy and "glocal” governance: revitalizing cosmopolitan democracy'. Innovation: The European Journal of Social Science, 29 (2): 134-160.

Conca, Ken. 2016. 'The changing shape of global environmental politics'. In Simon Nicholson and Sikina Jinnah (eds), New Earth Politics: Essays from the Anthropocene. Cambridge: The MIT Press, pp. 21-42.

Connolly, William E. 2011. A World of Becoming. Durham: Duke University Press. 
Crawford, Neta C. 2016. 'Studying World Politics as a complex adaptive system'. In Ken Booth and Toni Erskine (eds), International Relations Theory Today. Cambridge: Polity Press, pp. 263-267.

Crutzen, Paul J and Eugene F Stoermer. 2000. 'The "Anthropocene". Global Change Newsletter 41: 17-18.

Cudworth, Erika and Stephen Hobden. 2015. 'Complexifying International Relations for a posthumanist world'. In Emilian Kavalski (ed), World Politics at the Edge of Chaos: Reflections on Complexity and Global Life. New York: State University of New York Press. Kindle Edition.

Curtis, Simon. 2014. 'Introduction: empowering cities'. In Simon Curtis (ed), The Power of Cities in International Relations. New York: Routledge, pp 1-15. 455-477.

2016. 'Cities and global governance: state failure or a new global order?' Millennium, 44(3):

Dalby, Simon. 2011. 'Geographies of the international system: globalization, empire and the Anthropocene'. In Pami Aalto, Vilho Harle and Sami Moisio (eds), International Studies. Interdisciplinary Approaches. New York: Palgrave Macmillan, pp 125-148.

Dauvergne, Peter and Jennifer Clapp. 2016. 'Researching global environmental politics in the $21^{\text {st }}$ century'. Global Environmental Politics, 16 (1): 1-12.

Dean, Jonathan R, Melanie J Leng and Anson W Mackay. 2014. 'Is there an isotopic signature of the Anthropocene?' The Anthropocene Review, 1 (3): 276-287.

Erskine, Toni and Ken Booth. 2016. 'Conclusion: responsibility, risk, and IR theory'. In Ken Booth and Toni Erskine (eds), International Relations Theory Today. Cambridge: Polity Press, pp. 279-295. Fagan, Madeleine. 2016. 'Security in the Anthropocene: environment, ecology, escape. European Journal of International Relations. Published online before print.

Falk, Richard. 2016. 'Scholarship as citizenship' In Simon Nicholson and Sikina Jinnah (eds), New Earth Politics: Essays from the Anthropocene. Cambridge: The MIT Press, pp. 97-111.

Food and Agriculture Organization (FAO). 2014a. 'Precipitation and renewable freshwater resources'. AQUASTAT [online]. December. At http://www.fao.org/nr/water/aquastat/didyouknow/index. stm. [Accessed on 14 April 2016].

. 2014b. 'Water withdrawal and pressure on water resources'. AQUASTAT [online]. December. At http://www.fao.org/nr/water/aquastat/didyouknow/index2.stm. [Accessed on 14 April 2016].

Gillings, Michael R and Elizabeth L Hagan-Lawson. 2014. 'The cost of living in the Anthropocene'. Earth Perspectives, 1: 1-11.

Global Water Partnership (GWP). 2012. 'Increasing water security - a development imperative' [online]. At http://www.gwp.org/Global/About\%20GWP/Publications/Perspectives\%20Paper_ Water\%20Security_final.pdf. [Accessed on 18 March 2016].

Gordon, David J. 2016. 'The politics of accountability in networked urban climate governance'. Global Environmental Politics, 16 (2): 82-100.

Gupta, Joyeeta. 2016. 'Toward sharing our ecospace'. In Simon Nicholson and Sikina Jinnah (eds), New Earth Politics: Essays from the Anthropocene. Cambridge: The MIT Press, pp. 271-292.

Gupta, Joyeeta, Claudia Pahl-Wostl and Ruben Zondervan. 2013. 'Glocal' water governance: a multilevel challenge in the anthropocene'. Current Opinion in Environmental Sustainability, 5 (6): 573-580. Heng, Yee-Kuang. 2010. 'Ghosts in the machine: is IR eternally haunted by the spectre of old concepts?' International Politics, 47 (5): 535-556. 
Hoekstra, Arjen Y. 2014. 'Water for animal products: a blind spot in water policy'. Environmental Research Letters, 9: 1-3.

Howard, Ken WF. 2015. 'Sustainable cities and the groundwater governance challenge'. Environmental Earth Sciences, 73 (6): 2543-2554.

Intelligence Community Assessment (ICA). 2012. 'Global water security' [online]. At https://www. dni.gov/files/documents/Special\%20Report_ICA\%20Global\%20Water\%20Security.pdf. [Accessed on 24 March 2016].

Intergovernmental Panel on Climate Change (IPCC). 2014. Climate Change 2014: Synthesis Report (Contribution of Working Papers I, II, III to the Fifth Assessment Report of the Intergovernmental Panel on Climate Change). Geneva.

International Energy Agency (IEA). 2015. World Energy Outlook 2015. Paris: OCDE.

Janos, Nick and Corina McKendry. 2014. 'Globalization, governance, and renaturing the industrial city: Chicago, IL, and Seattle, WA'. In Simon Curtis (ed), The Power of Cities in International Relations. New York: Routledge, pp. 89-106.

Kavalski, Emilian. 2015. 'Complexifying IR: disturbing the "deep Newtonian slumber'. In Emilian Kavalski (ed), World Politics at the Edge of Chaos: Reflections on Complexity and Global Life. New York: State University of New York Press. Kindle Edition.

Keohane, Robert O. 2015. 'The global politics of climate change: challenge for Political Science'. Political Science, 48 (1): 19-26.

Kolbert, Elizabeth. 2014. The Sixth Extinction: An Unnatural History. New York: Henry Holt and Co. Larsen, Larissa. 2015. 'Urban climate and adaptation strategies'. Frontiers in Ecology and the Environment, 13 (9): 486-492.

Legislative Analyst's Office (LAO). 2015. '2014 GDP: California ranks 7th or 8th in the world'. California State Legislature [online]. 1 July. At http://www.lao.ca.gov/LAOEconTax/Article/Detail/90. [Accessed on 14 April 2016].

Ljungkvist, Kristin. 2014. 'The global city: from strategic site to global actor'. In Simon Curtis (ed), The Power of Cities in International Relations. New York: Routledge, pp. 32-56.

McDonald, Robert et al. 2014. Urban Water Blueprint: Mapping Conservation Solutions to The Global Water Challenge. Washington, DC: The Nature Conservancy.

Mitchell, Audra. 2014. 'Only human? A wordly approach to security'. Security Dialogue 45 (1): 5-21. . 2016. 'Is IR going extinct?' European Journal of International Relations, 00: 1-23.

National Oceanic and Atmospheric Administration (NOAA). 2015. 'Where is all of the Earth's Water?' National Ocean Service [online]. 10 September. At http://oceanservice.noaa.gov/facts/wherewater.html. [Accessed on 14 April 2016].

Nicholson, Simon and Sikina Jinnah. 2016. 'Living on a new Earth'. In Simon Nicholson and Sikina Jinnah (eds), New Earth Politics: Essays from the Anthropocene. Cambridge: The MIT Press, pp. 1-16.

Nijman, Janne. 2011. 'The future of the city and the international law of the future'. In Sam Muller et $\mathrm{al}$ (eds), The Law of the Future and the Future of the Law. Osolo: Torkel Opsahl Academic EPublisher, pp. 213-229.

O'Neill, Kate. 2016. 'Institutional politics and reform'. In Simon Nicholson and Sikina Jinnah (eds), New Earth Politics: Essays from the Anthropocene. Cambridge: The MIT Press, pp. 157-181. 
Organization for Economic Co-operation and Development (OECD). 2014. Managing Water for Future Cities. OECD Policy Perspectives: Managing Urban Water.

. 2015. Water and Innovation for Green Growth. OECD Policy Perspectives.

Pahl-Wostl, Claudia et al. 2013. 'Towards a sustainable water future: shaping the next decade of global water research'. Current Opinion in Environmental Sustainability, 5 (6): 708-714.

Pereira, Joana C. 2013. 'O Brasil e a governança climática global (2020-2024): entre o conservadorismo e o reformismo de vanguarda'. Carta Internacional, 8 (1): 91-110.

. 2015. 'Environmental issues and international relations, a new global (dis)order - the role of International Relations in promoting a concerted international system'. Revista Brasileira de Política Internacional, 58 (1): 191-209.

. 2016. 'Geoengineering, scientific community, and policymakers: a new proposal for the categorization of responses to anthropogenic climate change'. SAGE Open, 6 (1): 1-11.

Pflieger, Géraldine. 2016. 'Water as a source of conflict and cooperation'. Water Resources Management and Policy. University of Geneva, Coursera.

Population Reference Bureau (PRB). 2015. '2015 World population data sheet with a special focus on women's empowerement' [online]. At http://www.prb.org/pdf15/2015-world-population-datasheet_eng.pdf. [Accessed on 14 April 2016].

Rademacher, Anne. 2015. 'Urban political ecology'. The Annual Review of Anthropology, 44: 137-152.

Rist, Lucy, Adam Felton, Lars Samuelsson, Camilla Sandström and Ola Rosvall. 2013. 'A new paradigm for adaptive management'. Ecology and Society, 18 (4): 63.

Rockström, Johan et al. 2009. 'A safe operating space for humanity'. Nature, 461: 472-475.

. 2014. 'The unfolding water drama in the Anthropocene: towards a resilience-based perspective on water for global sustainability'. Ecohydrology, 7: 1249-1261.

Rosenberg, Justin. 2016. 'International Relations in the prison of Political Science. International Relations, 30 (2): 127-153.

Roudometof, Victor. 2015. 'The glocal and global studies'. Globalizations, 12 (5): 774-787.

Sadoff, Claudia W et al. 2015. Securing Water, Sustaining Growth: Report of the GWP/OCDE Task Force on Water Security and Sustainable Growth. Oxford: University of Oxford.

Savenije, Hubert HG, Arjen Y Hoekstra and Pieter van der Zaag. 2014. 'Evolving water science in the Anthropocene.' Hydrology and Earth System Sciences, 18: 319-332.

Schoeman, Jess, Catherine Allan and C Max Finlayson. 2014. 'A new paradigm for water? A comparative review of integrated, adaptive and ecosystem-based water management in the Anthropocene'. International Journal of Water Resources Development, 30 (3): 377-390.

Shi, Linda, Eric Chu, Isabelle Anguelovski, Alexander Aylett, Jessica Debats, Kian Goh, Todd Schenk, Karen C Seto, David Dodman, Debra Roberts, J Timmons Roberts and Stacy D VanDeveer. 2016. 'Roadmap towards justice in urban climate adaptation research'. Nature Climate Change, 6: 131-137.

Sivapalan, Murugesu et al. 2014. 'Socio-hydrology: use-inspired water sustainability science for the Anthropocene'. Earth's Future, 2: 225-230.

Steffen, Will, Paul J Crutzen and John R McNeill. 2007. 'The Anthropocene: are humans now overwhelming the great forces of nature?' Ambio 36: 614-617. 
Sylvester, Christine. 2016. 'Must IR remain abstract in the future?' In Ken Booth and Toni Erskine (eds), International Relations Theory Today. Cambridge: Polity Press, pp 258-262.

The Water Project (TWP). 2014. 'Facts about water: statistics of the water crisis' [online]. At https:// thewaterproject.org/water-scarcity/water_stats. [Accessed on 14 April 2016].

United Nations (UN). 2014. World Urban Prospects. New York.

n.d. 'Sustainable Development Goals: 17 goals to transform our world' [online]. At http:// www.un.org/sustainabledevelopment/sustainable-development-goals/. [Accessed on 14 April 2016]. United Nations World Water Assessment Programme (UN-WWAP). 2015. The United Nations World Water Development Report 2015: Water for a Sustainable World. Paris.

United Nations-Water (UN-Water). 2013. Water Security \& the Global Water Agenda: A UN-Water Analytical Brief. Ontario: United Nations University.

United Nations Environmental Programme (UNEP). 2012. Global Environment Outlook 5. At http:// www.unep.org/geo/geo/assessments/global-assessments/global-environment-outlook-5. [Accessed on 3 May 2017.]

Vörösmarty, Charles J et al. 2010. 'Global threats to human water security and river biodiversity'. Nature, 467: 555-561.

2013. 'Global water, the anthropocene and the transformation of a science.' Current Opinion in Environmental Sustainability, 5 (6): 539-550.

Vörösmarty, Charles J, Claudia Pahl-Wostl and Anik Bhaduri. 2013. 'Water in the anthropocene: new perspectives for global sustainability'. Current Opinion in Environmental Sustainability, 5 (6): 1-4.

Wheater, Howard S. 2015. 'Water security - science and management challenges'. Proceedings of the International Association of Hydrological Sciences, 366: 23-30.

Wichelns, Dennis. 2015. 'Virtual water and water footprints: Overreaching into the discourse on sustainability, efficiency, and equity'. Water Alternatives, 8 (3): 396-414.

World Economic Forum (WEF). 2011. Water Security: The Water-Food-Energy-Climate Nexus. Washington, DC: Island Press.

2015. Global Risks 2015. Geneva.

Worldometers. 2015. 'Water consumption statistics' [online]. At http://www.worldometers.info/water/. [Accessed on 14 April 2016].

Young, Oran R. 2016. 'International Relations in the Anthropocene'. In Ken Booth and Toni Erskine (eds), International Relations Theory Today. Cambridge: Polity Press, pp. 231-252.

Zalasiewicz, Jan, Mark Williams, Will Steffen and Paul Crutzen. 2010. 'The new world of the Anthropocene'. Environmental Science \& Technology, 44: 2228-2231.

\section{About the authors}

Joana Castro Pereira holds a $\mathrm{PhD}$ in International Relations/Globalization and Environment from the New University of Lisbon, and a BA in Languages and International Relations from the University of Porto, Portugal. She is Assistant Professor of International Relations in the Lusíada University-North (Porto) Faculty of Law, Associate Researcher at the Portuguese Institute of International Relations (IPRI-NOVA), and a Post-doctoral 
Fellow of the Institute of International Relations of the University of Brasília. Her research interests include the international system in the Anthropocene, international political economy of climate change, global governance, and geo-engineering. Her latest publication is 'Geoengineering, scientific community, and policymakers: a new proposal for the categorization of responses to anthropogenic climate change' (SAGE Open, 2016).

Miguel Rodrigues Freitas holds a Postgraduate Degree in Urban Engineering/Sustainable Cities from the University of Minho, and a BA in Civil Engineering from the Polytechnic of Porto - School of Engineering, Portugal. Since 2008, he has worked in the water sector at the Department of Studies and Planning of Águas do Norte, SA (AdP Group, Portugal - www.adp.pt/en). He is a Masters Candidate in Urban Engineering at the University of Minho. His dissertation is a critical review of the usefulness of different water performance indicators for water resources management and policy. His current research interests include efficiency, security, management and governance of water systems.

\title{
Cidades e Segurança Hídrica no Antropoceno: Desafios e Oportunidades de Pesquisa para a Disciplina das Relações Internacionais
}

\begin{abstract}
Resumo: As cidades têm se tornado atores importantes nas relações internacionais e essenciais nas políticas de segurança e meio ambiente. Vivemos em um mundo cada vez mais urbano, dominado por aglomerados e atividades humanas. O papel central desempenhado pelos seres humanos na alteração da estrutura física do planeta nos levou a uma época geológica incerta, instável e perigosa - o Antropoceno -, trazendo grandes desafios adicionais à questão da segurança. Esferas locais e globais estão mais conectadas do que nunca, gerando problemas "glocais" nos quais a água desempenha um papel central. A água é o elemento que interliga a complexa rede de alimentos, energia, clima, crescimento econômico e segurança humana. Em um mundo em rápida urbanização, as cidades influenciam o ciclo hidrológico de maneiras significativas, porém incertas, afetando os recursos hídricos além de seus limites. Não há dúvida de que essas questões são altamente relevantes para a disciplina das Relações Internacionais (RI). Entretanto, os estudiosos das RI têm mostrado lentidão ao se engajar com este tema, e a maioria dos estudos acadêmicos das cidades e da segurança hídrica ainda advêm das ciências naturais. Este artigo examina as formas pelas quais as cidades no Antropoceno desafiam a segurança hídrica e por que a área das RI precisa se reinventar se quiser manter sua contribuição à temática da segurança global.
\end{abstract}


Palavras-chave: Urbanização; Cidades; Antropoceno; Segurança Hídrica; Desafios Glocais; Relações Internacionais.

Received on 29 July 2016, and approved for publication on 21 February 2017. 